\title{
Influence of $\mathrm{CeO}_{2}$ nanocrystals size on the vacancies formation processes determined by spectroscopic techniques
}

\author{
P.O.Maksimchuk, V.V.Seminko, I.I.Bespalova, A.A.Masalov \\ Institute for Scintillation Materials, STC "Institute for Single Crystals", \\ National Academy of Sciences of Ukraine, \\ 60 Lenin Ave., 61001 Kharkiv, Ukraine
}

Received April 22, 2014

In the paper influence of the size on the processes of oxygen vacancies formation in $\mathrm{CeO}_{2}$ nanocrystals has been investigated. Changes in concentration of oxygen vacancies were determined by two independent indicators: intensity of $5 d \rightarrow 4 f$ luminescence of $\mathrm{Ce}^{3+}$ ions and ratio between ${ }^{5} D_{0} \rightarrow{ }^{7} F_{1}$ and ${ }^{5} D_{0} \rightarrow{ }^{7} F_{2}$ luminescence bands of $\mathrm{Eu}^{3+}$ ions incorporated into ceria nanocrystals as structural probes. It was shown that for $\mathrm{CeO}_{2}$ nanocrystals decrease of the size (from $75 \mathrm{~nm}$ to $20 \mathrm{~nm}$ ) manifests itself in 1.5 times increase of the band intensity associated with vacancy-stabilized $\mathrm{Ce}^{3+}$ ions, while for $\mathrm{CeO}_{2}: \mathrm{Eu}^{3+}$ nanocrystals it leads to lowering of symmetry for $\mathrm{Eu}^{3+}$ centre and correspondent decrease of ${ }^{5} D_{0} \rightarrow{ }^{7} F_{1} /{ }^{5} D_{0} \rightarrow{ }^{7} F_{2}$ intensity ratio. It was shown that decrease of the size stimulates formation of the oxygen vacancies in ceria nanoparticles.

Исследовано влияние размера на процессы формирования кислородных вакансий в нанокристаллах $\mathrm{CeO}_{2}$. Для определения изменения концентрации кислородных вакансий использовано два независимых показателя - интенсивность $5 d \rightarrow 4 f$ люминесценции ионов $\mathrm{Ce}^{3+}$ и отношение между ${ }^{5} D_{0} \rightarrow{ }^{7} F_{1}$ и ${ }^{5} D_{0} \rightarrow{ }^{7} F_{2}$ люминесцентными полосами ионов $\mathrm{Eu}^{3+}$, введенных в нанокристаллы в качестве структурных зондов. Показано, что для нанокристаллов $\mathrm{CeO}_{2}$ уменьшение размера (от 75 до 20 нм) приводит к возрастанию в 1,5 раза интенсивности полосы, связанной с ионами $\mathrm{Ce}^{3+}$, стабилизированными кислородными вакансиями, тогда как для нанокристаллов $\mathrm{CeO}_{2}: \mathrm{Eu}^{3+}$ уменьшение размеров приводит $к$ понижению симметрии центра $\mathrm{Eu}^{3+}$ и соответствующего снижения значения отношения ${ }^{5} D_{0} \rightarrow{ }^{7} F_{1} /{ }^{5} D_{0} \rightarrow{ }^{7} F_{2}$. Полученные результаты позволяют определить, что уменьшение размера стимулирует формирование кислородных вакансий в наночастицах $\mathrm{CeO}_{2}$.

Вплив розміру на процеси формування вакансій у нанокристалах $\mathrm{CeO}_{2}$, встановлений за допомогою спектроскопічних методів. П.О.Максилчук, В.В.Семінько, I.І.Бес палова, А.О.Масалов.

Досліджено вплив розміру на процеси формування кисневих вакансій у нанокристалах $\mathrm{CeO}_{2}$. Для визначення зміни концентрації кисневих вакансій використано два незалежні показники - інтенсивність $5 d \rightarrow 4 f$ люмінесценції іонів $\mathrm{Ce}^{3+}$ та відношення між ${ }^{5} D_{0} \rightarrow{ }^{7} F_{1}$ та ${ }^{5} D_{0} \rightarrow{ }^{7} F_{2}$ люмінесцентними смугами іонів $\mathrm{Eu}^{3+}$, введених у нанокристали в якості структурних зондів. Показано, що для нанокристалів $\mathrm{CeO}_{2}$ зменшення розміру (від 75 нм до 20 нм) призводить до зростання у 1,5 рази інтенсивності смуги, пов'язаної 3 іонами $\mathrm{Ce}^{3+}$, стабілізованими вакансіями, тоді як для нанокристалів $\mathrm{CeO}_{2}: \mathrm{Eu}^{3+}$ зменшення розмірів призводить до зниження симетрії центра $\mathrm{Eu}^{3+}$ та відповідного зниження значення відношення ${ }^{5} D_{0} \rightarrow{ }^{7} F_{1} /{ }^{5} D_{0} \rightarrow{ }^{7} F_{2}$. Отримані результати дозволяють визначити, що зменшення розміру стимулює формування кисневих вакансій у наночастках $\mathrm{CeO}_{2}$. 


\section{Introduction}

Ceria $\left(\mathrm{CeO}_{2}\right)$ is well-known material which is widely used for creation of ionic conductors, fuel cells and UV-protective coatings [1-3]. Recently it was successfully applied in biology as an effective ROS (Reactive Oxygen Species)-defending agent similar in its properties to catalase protein [4]. Unique properties of ceria are connected with effective $\mathrm{Ce}^{3+}-\mathrm{Ce}^{4+}$ oxidation/reduction processes determined by low energy of oxygen vacancies formation in this material (formation of the complex defect $\mathrm{Ce}^{3+}-\mathrm{O}_{V}-\mathrm{Ce}^{3+}$ with the vacancy situated at $\mathrm{NN}$ site to $\mathrm{Ce}^{3+}$ ion requires only $0.26 \mathrm{eV}$ ) [5]. Creation of each oxygen vacancy is accompanied by transition of two $\mathrm{Ce}^{4+}$ ions to $\mathrm{Ce}^{3+}$ ones, so oxygen vacancy concentration and $\mathrm{Ce}^{3+} / \mathrm{Ce}^{4+}$ ratio are directly proportional to each other. Extremely high concentrations of the oxygen vacancies (and correspondingly, $\mathrm{Ce}^{3+}$ ions) in ceria nanoparticles were recently determined by EMR (about $18 \%$ of $\mathrm{Ce}^{3+}$ ions for $3 \mathrm{~nm}$ nanoparticles) [6] and XPS investigations $\left(17 \%\right.$ of $\mathrm{Ce}^{3+}$ ions for $30 \mathrm{~nm}$ and up to $44 \%$ for $3 \mathrm{~nm}$ nanoparticles) [7].

In [5] it was shown that oxygen vacancies in ceria are formed preferentially in the nearest-neighbor $(\mathrm{NN})$ position to $\mathrm{Ce}^{3+}$ ions that was confirmed spectroscopically in [8]. As was shown [8], luminescent properties of $\mathrm{CeO}_{2}$ nanocrystals are determined by two different luminescent centers formed by $\mathrm{Ce}^{3+}$ ions and $\mathrm{Ce}^{4+}-\mathrm{O}^{2-}$ charge transfer (CT) states. $5 d \rightarrow 4 f$ Luminescence intensity of $\mathrm{Ce}^{3+}$ ions increases strongly with increase of concentration of the oxygen vacancies that allows to considerate this intensity as a measure of the oxygen vacancies concentration in ceria nanocrystals. Incorporation of trivalent (for instance, rare-earth) ion instead of $\mathrm{Ce}^{4+}$ leads to formation of the oxygen vacancies required for compensation of excess negative charge. Relative position of the oxygen vacancies and rareearth (RE) ions in RE-doped ceria nanocrystal was investigated recently in the few papers [9]. In [10] it was theoretically shown that for ions with radius smaller than radius of $\mathrm{Gd}^{3+}$ ion the oxygen vacancy is localized preferentially on the NN position to the $\mathrm{RE}$ ion, while for the ions with radius bigger than radius of $\mathrm{Gd}^{3+}$ (such as $\mathrm{Eu}^{3+}$ ions) the vacancy is repelled to NNN (next to nearest-neighbor) position. According to these predictions the surrounding of $\mathrm{Eu}^{3+}$ ion must preserve $O_{h}$ symmetry and only magneto-dipole transitions of $\mathrm{Eu}^{3+}$ (such as $\left.{ }^{5} D_{0} \rightarrow{ }^{7} F_{1}\right)$ are possible [10]. However, in [9] it was shown that in $\mathrm{CeO}_{2}: \mathrm{Eu}^{3+}$ there are up to four additional positions of $\mathrm{Eu}^{3+}$ ion with symmetry lower than $O_{h}$ that manifests itself in occurrence of electro-dipole ${ }^{5} D_{0} \rightarrow{ }^{7} F_{2}$ transition (forbidden for $\mathrm{Eu}^{3+}$ centers in $O_{h}$ positions) in luminescence spectra of Eu-doped ceria. Moreover, the number of $\mathrm{Eu}^{3+}$ ions in distorted states increases strongly with Eu concentration and calcination temperature increase [11]. As was supposed in [11], $\mathrm{Eu}^{3+}$ ions in ceria can act as traps of the oxygen vacancies located in the NN positions to the ion and increase of the vacancy concentration (due to annealing temperature or $\mathrm{Eu}^{3+}$ content increase) leads to sufficient increase of the number of $\mathrm{Eu}^{3+}$ ions in distorted positions. So, the relative content of $\mathrm{Eu}^{3+}$ ions in positions with non-cubic symmetry also can be a measure of the oxygen vacancies concentration in nanocrystals.

In this paper we have used the intensity of $5 d \rightarrow 4 f$ luminescence of $\mathrm{Ce}^{3+}$ ions and the ratio between intensities of ${ }^{5} D_{0} \rightarrow{ }^{7} F_{1} \quad$ (symmetry insensitive) and ${ }^{5} D_{0} \rightarrow{ }^{7} F_{2}$ (symmetry sensitive) transitions of $\mathrm{Eu}^{3+}$ as indicators that allow to determine the change of the oxygen vacancies concentration in $\mathrm{CeO}_{2}$ nanocrystals depending on their size and to estimate the correspondent concentrations of the oxygen vacancies in these nanocrystals.

\section{Experimental}

$\mathrm{CeO}_{2}$ nanocrystals were obtained by Pechini method, $\mathrm{CeO}_{2}: \mathrm{Eu}^{3+}(0.2,2,6$ and 10 at. \%) nanocrystals were synthesized by colloidal precipitation method. $\mathrm{CeO}_{2}$ nanocrystals were dispersed in water and fractions with different sedimentation rates were taken and placed on the quartz. The average sizes of nanocrystals taken from each fraction was determined from equation $r=9 \eta 2 g\left(\rho-\rho_{0}\right) H t$, where $\eta$ is viscosity coefficient, $\rho$ and $\rho_{0}$ are densities of precipitant and water, respectively, $H / t$ is deposition rate. Luminescence of all samples was excited by He-Cd laser $\left(\lambda_{\text {exc }}=325 \mathrm{~nm}\right)$. Luminescence spectra of $\mathrm{CeO}_{2}$ nanocrystals were taken at $77 \mathrm{~K}$, spectra of $\mathrm{CeO}_{2}: \mathrm{Eu}^{3+}$ nanocrystals were taken at $300 \mathrm{~K}$.

\section{Results and discussion}

As was recently shown in [8], optical properties of $\mathrm{CeO}_{2}$ nanocrystals are deter- 
mined by presence of two different optical centers formed by $\mathrm{Ce}^{3+}$ ions and $\mathrm{Ce}^{4+}-\mathrm{O}^{2-}$ charge transfer states. Luminescence spectra of $\mathrm{CeO}_{2}$ nanoparticles (shown in Fig. 1) consist of two spectral bands with maximums at $390 \mathrm{~nm}$ and $620 \mathrm{~nm}$ accordingly. The band at $390 \mathrm{~nm}$ is temperature-independent but its intensity increases strongly at atmosphere variation from oxidizing to reducing. This band was ascribed in [8] to $5 d \rightarrow 4 f$ transitions of $\mathrm{Ce}^{3+}$ ions. In reducing atmosphere concentration of the oxygen vacancies and, correspondingly, of $\mathrm{Ce}^{3+}$ ions (that require oxygen vacancies for charge compensation) is much more than in oxidizing atmosphere, so the dependence of this band intensity on the atmosphere of treatment can be easily explained. The band at $620 \mathrm{~nm}$ exhibit strong quenching with temperature increase and slightly depends on the atmosphere of treatment. It was ascribed to charge-transfer luminescence of $\mathrm{Ce}^{4+}-\mathrm{O}^{2-}$ complex. As CT luminescence is independent on the vacancy concentration, relative intensity of $\mathrm{Ce}^{3+} 5 d-4 f$ luminescence can be used as a measure of $\mathrm{Ce}^{3+}$ (and oxygen vacancies) concentration in ceria nanocrystals with different sizes. In the Fig. 1 the luminescence spectra of $\mathrm{CeO}_{2}$ nanocrystals $\left(\lambda_{\text {exc }}=325 \mathrm{~nm}\right)$ with sizes of about $20 \mathrm{~nm}, 50 \mathrm{~nm}$ and $75 \mathrm{~nm}$ are shown. Decrease of the size from $75 \mathrm{~nm}$ to $20 \mathrm{~nm}$ leads to increase in 1.5 times of intensity of $390 \mathrm{~nm}$ band associated with $5 d \rightarrow 4 f$ luminescence of $\mathrm{Ce}^{3+}$ ion. Intensity of this band is directly proportional to $\mathrm{Ce}^{3+}$ concentration and, correspondingly, to concentration of oxygen vacancies in the nanocrystal. So, it can be concluded that decrease of the size of the ceria nanoparticles from $75 \mathrm{~nm}$ to $50 \mathrm{~nm}$ and from $50 \mathrm{~nm}$ to $20 \mathrm{~nm}$ leads to 1.25 and 1.5 times increase of the oxygen vacancy concentration.

$\mathrm{Eu}^{3+}$ ion is widely used for determination of local structure of cationic centers in different crystal matrices [12]. It is connected with high sensitivity of electro-dipole ${ }^{5} D_{0} \rightarrow{ }^{7} F_{2}$ transition of $\mathrm{Eu}^{3+}$ ion to presence or absence of inversion center of symmetry. Contrary to ${ }^{5} D_{0} \rightarrow{ }^{7} F_{2}$ transition, intensity of magneto-dipole ${ }^{5} D_{0} \rightarrow{ }^{7} F_{1}$ transition of $\mathrm{Eu}^{3+}$ ion is practically independent on the symmetry of cationic center. So the ratio between the intensities of ${ }^{5} D_{0} \rightarrow{ }^{7} F_{1}$ and ${ }^{5} D_{0} \rightarrow{ }^{7} F_{2}$ transitions provides an information about local symmetry of the $\mathrm{Eu}^{3+}$ surrounding symmetry.

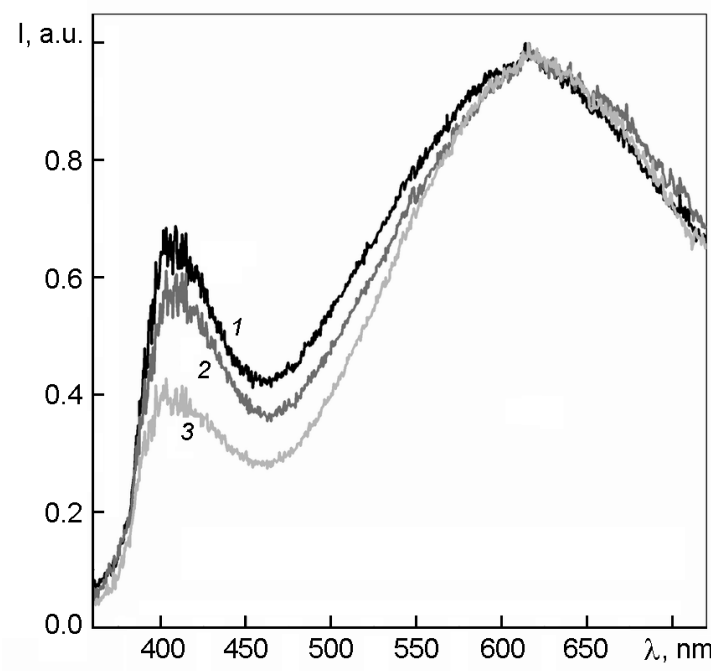

Fig. 1. Luminescence spectra of $\mathrm{CeO}_{2}$ nanocrystals $(1-20 \mathrm{~nm}, 2-50 \mathrm{~nm}, 3-$ $75 \mathrm{~nm})$.

Due to incorporation of trivalent ions instead of tetravalent the treatment in reducing atmosphere must lead to formation of additional oxygen vacancies in the ceria lattice. To trace the process of oxygen vacancies formation during the high-temperature treatment in different atmospheres ratio between ${ }^{5} D_{0} \rightarrow{ }^{7} F_{1}$ and ${ }^{5} D_{0} \rightarrow{ }^{7} F_{2} \quad$ intensities of $\mathrm{Eu}^{3+}$ ion can be used. Formation of the oxygen vacancy near $\mathrm{Eu}^{3+}$ ion must lead to sufficient change of its ligand surrounding. If the vacancy is located outside the first coordination sphere the surroundings of doped ion must preserve $O_{h}$ symmetry point group, if the vacancy is located in the first coordination sphere of doped ion, the symmetry of cation center changes to $C_{3 v}$ or lower. As was shown in [11] increase of $\mathrm{Eu}^{3+}$ concentration (and, correspondingly, of the oxygen vacancies) leads to proportional increase of the number of centers with non-cubic symmetry determined by change of ${ }^{5} D_{0} \rightarrow{ }^{7} F_{1} /{ }^{5} D_{0} \rightarrow{ }^{7} F_{2}$ ratio. The influence of the atmosphere treatment on the vacancies concentration can be determined in the same way. In our experiment the concentrations of $\mathrm{Eu}^{3+}$ in $\mathrm{CeO}_{2}$ were very low (about 0.2 at. $\%, C_{v a c}=0.05 \%$ ) to exclude from consideration the vacancies created by incorporation of $\mathrm{Eu}^{3+}$ ion instead of $\mathrm{Ce}^{4+}$ and to deal mostly with the vacancies provided by change of the atmosphere treatment.

Luminescence spectra of $\mathrm{CeO}_{2}: \mathrm{Eu}^{3+}$ nanocrystals $(10 \mathrm{~nm})$ at treatment atmosphere variation are shown in the Fig. 2 . It consist of characteristic ${ }^{5} D_{0} \rightarrow{ }^{7} F_{1}$ and 


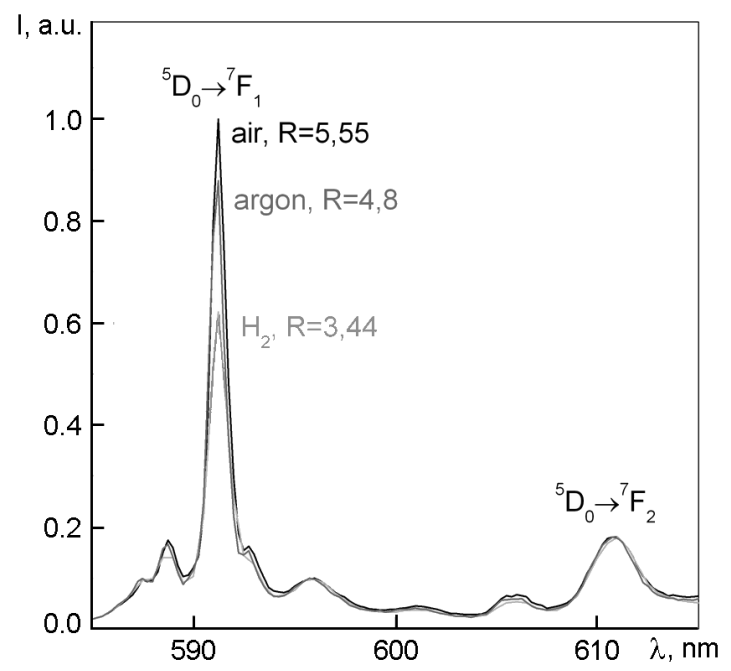

Fig. 2. Luminescence spectra of $\mathrm{CeO}_{2}: \mathrm{Eu}^{3+}$ nanocrystals $(10 \mathrm{~nm})$ treated in oxidizing (air), neutral (Ar) and reducing $\left(\mathrm{H}_{2}\right)$ atmosphere.

${ }^{5} D_{0} \rightarrow{ }^{7} F_{2}$ bands at $590 \mathrm{~nm}$ and $610 \mathrm{~nm}$, respectively. The ratio between ${ }^{5} D_{0} \rightarrow{ }^{7} F_{1}$ and ${ }^{5} D_{0} \rightarrow{ }^{7} F_{2}$ bands is about 5.6 for oxidizing atmosphere, 4.8 for neutral atmosphere and 3.4 for reducing atmosphere. Low intensity of ${ }^{5} D_{0} \rightarrow{ }^{7} F_{2}$ band as compared to ${ }^{5} D_{0} \rightarrow{ }^{7} F_{1}$ band for all atmospheres allows to determine that vacancies are located preferentially outside the first coordination sphere of $\mathrm{Eu}^{3+}$ ion and surrounding of $\mathrm{Eu}^{3+}$ ion preserve cubic symmetry. While the radius of $\mathrm{Eu}^{3+}$ ion is bigger than radius of $\mathrm{Gd}^{3+}$ ion, it corresponds well with predictions [10] that such ions must have a charge compensating defect in the NNN but not NN positions. At the same time for reducing atmosphere the portion of $\mathrm{Eu}^{3+}$ centers with $O_{h}$ symmetry is the lowest as compared to ones obtained after treatment in oxidizing and neutral media. However the relative intensity of ${ }^{5} D_{0} \rightarrow{ }^{7} F_{1}$ band is still higher than the one of ${ }^{5} D_{0} \rightarrow{ }^{7} F_{2}$ band, so even for reducing atmosphere most of $\mathrm{Eu}^{3+}$ ions do not have a vacancy on the NN position. As a cause of increase of the portion of noncubic centers for neutral and reducing atmosphere, increase of oxygen vacancies content leading to formation of "vacancy $\mathrm{Eu}^{3+"}$ associates and distortion of $O_{h}$ symmetry can be suggested [9].

Luminescence spectra of $\mathrm{CeO}_{2}: \mathrm{Eu}^{3+}$ nanocrystals of different sizes $(10 \mathrm{~nm}$, $25 \mathrm{~nm}$ and $50 \mathrm{~nm}$ ) are shown in the Fig. 3. For all sizes the ratio between ${ }^{5} D_{0} \rightarrow{ }^{7} F_{1}$ and ${ }^{5} D_{0} \rightarrow{ }^{7} F_{2}$ bands depends on the atmos-
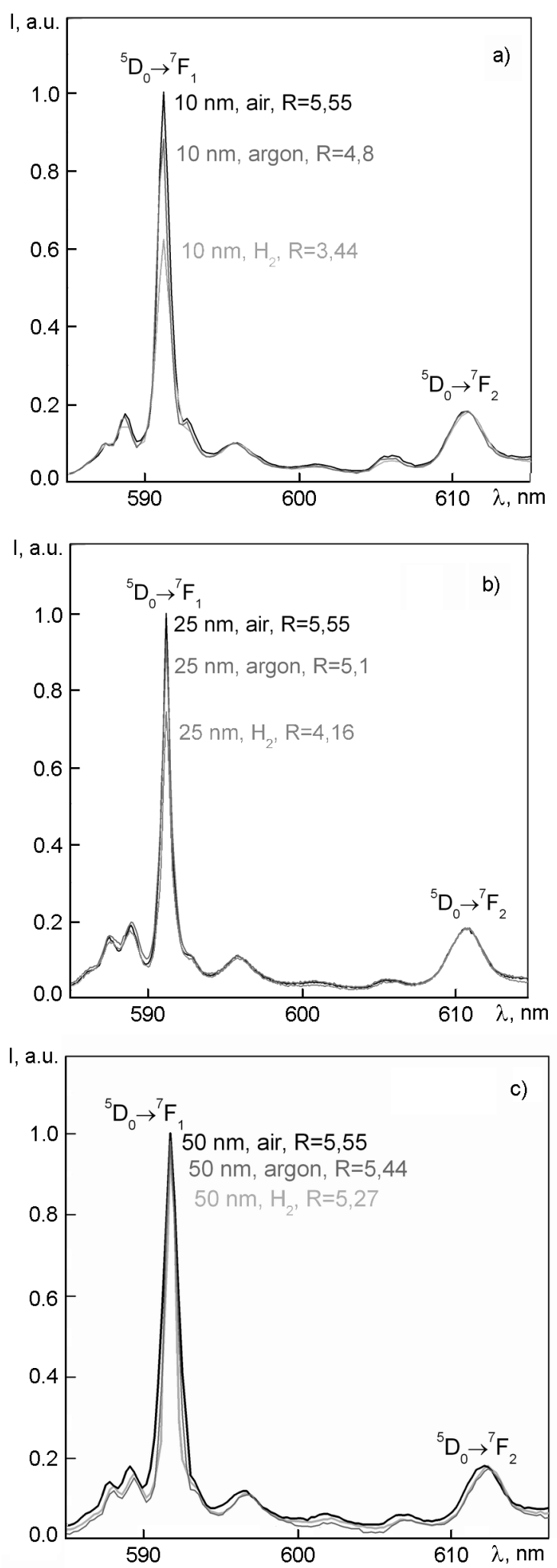

Fig. 3. Luminescence spectra of $\mathrm{CeO}_{2}: \mathrm{Eu}^{3+}$ nanocrystals treated in oxidizing (air), neutral (Ar) and reducing $\left(\mathrm{H}_{2}\right)$ atmosphere $(\mathrm{a}-$ $10 \mathrm{~nm}, \mathrm{~b}-25 \mathrm{~nm}, \mathrm{c}-50 \mathrm{~nm})$. 
phere of treatment and for reducing atmosphere the value of this ratio is the smallest. The values of ${ }^{5} D_{0} \rightarrow{ }^{7} F_{1} /{ }^{5} D_{0} \rightarrow{ }^{7} F_{2}$ ratio for nanocrystals with different sizes are summarized in Table. Decrease of the size from $50 \mathrm{~nm}$ to $10 \mathrm{~nm}$ leads to increase of the portion of non-cubic sites formed after treatment in reducing atmosphere. So it can be supposed that concentration of the vacancies in smaller $\mathrm{CeO}_{2}$ nanoparticles is more than in the bigger ones.

For estimation of the oxygen vacancies concentration in $\mathrm{CeO}_{2}: \mathrm{Eu}^{3+}$ nanocrystals of different sizes the dependence of ${ }^{5} D_{0} \rightarrow{ }^{7} F_{1} /{ }^{5} D_{0} \rightarrow{ }^{7} F_{2}$ ratio on the concentration of the vacancies was determined. Introduction of two $\mathrm{Eu}^{3+}$ ions instead of $\mathrm{Ce}^{4+}$ ones into stoichiometric $\mathrm{CeO}_{2}$ lattice leads to formation of one oxygen vacancy required for compensation of excess negative charge. So, in $\mathrm{CeO}_{2}: \mathrm{Eu}^{3+}$ treated in the oxidizing atmosphere the oxygen vacancies concentration will be proportional to the concentration of $\mathrm{Eu}^{3+}$ ions and particular ratio between ${ }^{5} D_{0} \rightarrow{ }^{7} F_{1}$ and ${ }^{5} D_{0} \rightarrow{ }^{7} F_{2}$ bands can be assigned to the particular vacancy concentration.

The luminescence spectra of $\mathrm{CeO}_{2}: \mathrm{Eu}^{3+}$ nanocrystals with different $\mathrm{Eu}^{3+}$ concentrations are shown in Fig. 4. Increase of $\mathrm{Eu}^{3+}$ concentration from 2 at. $\%$ to 10 at.\% leads to decrease of intensity of ${ }^{5} D_{0} \rightarrow{ }^{7} F_{1}$ luminescence band. So the number of $\mathrm{Eu}^{3+}$ centers with $O_{h}$ symmetry also decreases with increase of $\mathrm{Eu}^{3+}$ concentration in agreement with results obtained in [11]. Preferential formation of $\mathrm{Eu}^{3+}$ centers with the symmetry lower than $O_{h}$ for high Eu ${ }^{3+}$ concentrations is determined by high concentrations of the oxygen vacancies required for compensation of additional charge of doped ions and formation of the $\mathrm{Eu}^{3+}$-oxygen vacancy associates [9].

As was mentioned before, for $\mathrm{CeO}_{2}: \mathrm{Eu}^{3+}$ nanocrystals treated in oxidizing atmosphere the oxygen vacancies concentration is proportional to the concentration of $\mathrm{Eu}^{3+}$ ions (for instance, 0.2 at. $\%$ of $\mathrm{Eu}^{3+}$ ions

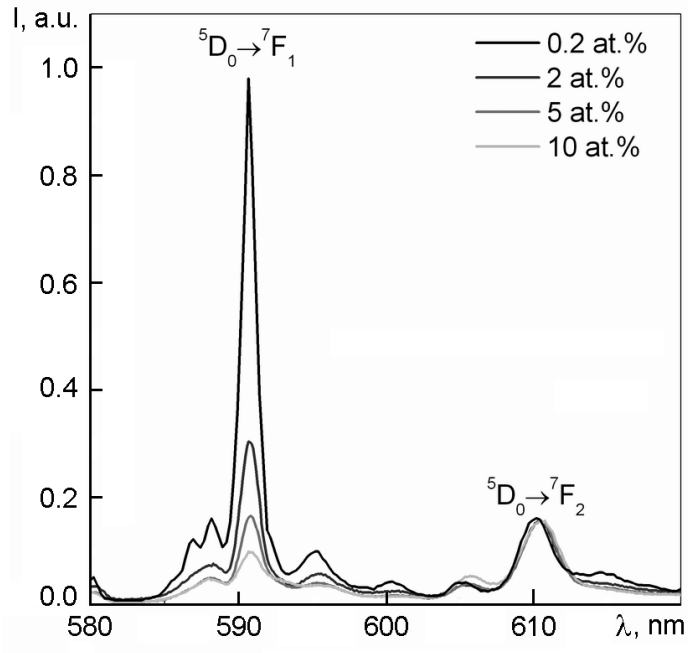

Fig. 4. Luminescence spectra of $\mathrm{CeO}_{2}: \mathrm{Eu}^{3+}$ nanocrystals $(0.2,2,5$ and 10 at. $\%)$.

corresponds to $0.05 \%$ of oxygen vacancies). So, dependence of ${ }^{5} D_{0} \rightarrow{ }^{7} F_{1} /{ }^{5} D_{0} \rightarrow{ }^{7} F_{2}$ ratio on the concentration of $\mathrm{Eu}^{3+}$ ions can be considered as dependence of this ratio on the concentration of the oxygen vacancies ions as well. This dependence is shown in Fig. 5. The values of ${ }^{5} D_{0} \rightarrow{ }^{7} F_{1} /{ }^{5} D_{0} \rightarrow{ }^{7} F_{2}$ ratio for $\mathrm{CeO}_{2}: \mathrm{Eu}^{3+}$ nanocrystals with different sizes and treated in different atmospheres (determined from Fig. 3) are shown by asterisks. Comparison of the values of ${ }^{5} D_{0} \rightarrow{ }^{7} F_{1} /{ }^{5} D_{0} \rightarrow{ }^{7} F_{2}$ ratio for nanocrystals with the different sizes and with the different concentrations of $\mathrm{Eu}^{3+}$ ions allows to determine that concentration of the oxygen vacancies increases with decrease of the size of nanocrystals: from $0.07 \%(50 \mathrm{~nm})$ to $0.125 \%(10 \mathrm{~nm})$ at treatment in neutral atmosphere and from $0.08 \%(50 \mathrm{~nm})$ to $0.33 \%(10 \mathrm{~nm})$ at treatment in reducing atmosphere (Table). Such increase of the oxygen vacancies concentration can be explained by the higher surface/volume ratio and decrease of an activation e nergy for the small $\mathrm{CeO}_{2}: \mathrm{Eu}^{3+}$ nanocrystals [13].

Table. Values of ${ }^{5} D_{0} \rightarrow{ }^{7} F_{1} /{ }^{5} D_{0} \rightarrow{ }^{7} F_{2}$ ratio and concentration of oxygen vacancies for $\mathrm{CeO}_{2}: \mathrm{Eu}^{3+}$ nanocrystals with the different sizes and treated in different atmospheres

\begin{tabular}{|c|c|c|c|c|c|c||}
\hline \hline Size & $R($ air $)$ & $R(\mathrm{Ar})$ & $R\left(\mathrm{H}_{2}\right)$ & $C_{v}, \%$ (air) & $C_{v}, \%(\mathrm{Ar})$ & $C_{v}, \%\left(\mathrm{H}_{2}\right)$ \\
\hline $10 \mathrm{~nm}$ & 5.55 & 4.8 & 3.44 & 0.05 & 0.125 & 0.33 \\
$25 \mathrm{~nm}$ & 5.55 & 5.1 & 4.16 & 0.05 & 0.1 & 0.2 \\
$50 \mathrm{~nm}$ & 5.55 & 5.44 & 5.27 & 0.05 & 0.07 & 0.08 \\
\hline
\end{tabular}




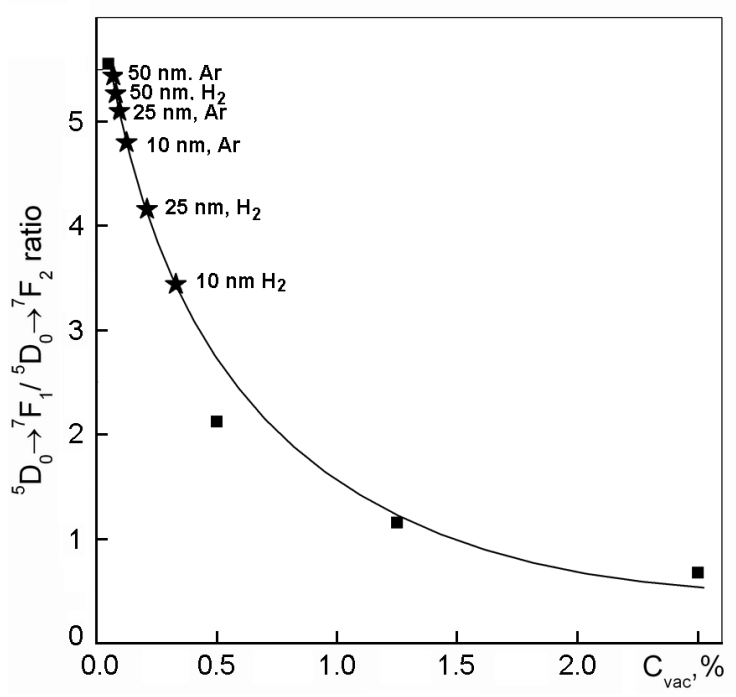

Fig. 5. Dependence of ${ }^{5} D_{0} \rightarrow{ }^{7} F_{1} /{ }^{5} D_{0} \rightarrow{ }^{7} F_{2}$. ratio on the oxygen vacancies concentration. Values of ${ }^{5} D_{0} \rightarrow{ }^{7} F_{1} /{ }^{5} D_{0} \rightarrow{ }^{7} F_{2}$ ratio for $\mathrm{CeO}_{2}: \mathrm{Eu}^{3+}$ nanocrystals with the different sizes and treated in different atmospheres are shown by asterisks.

\section{Conclusions}

In the paper an influence of the size on the processes of oxygen vacancies formation in $\mathrm{CeO}_{2}$ nanocrystals has been investigated by means of spectroscopic techniques using intensity of $5 d \rightarrow 4 f$ luminescence of $\mathrm{Ce}^{3+}$ ions and ${ }^{5} D_{0} \rightarrow{ }^{7} F_{1} /{ }^{5} D_{0} \rightarrow{ }^{7} F_{2}$ ratio of $\mathrm{Eu}^{3+}$ bands as indicators of the oxygen vacancies concentration. Both methods allow to determine sufficient increase of the vacancy concentration with decrease of the size of nanocrystal. Increase in 1.5 times of $5 d \rightarrow 4 f$ luminescence intensity of $\mathrm{Ce}^{3+}$ ions corresponding to the same increase in the vacancies concentration with decrease of the size from $75 \mathrm{~nm}$ to $20 \mathrm{~nm}$ was shown for undoped $\mathrm{CeO}_{2}$ nanocrystals. For $\mathrm{CeO}_{2}: \mathrm{Eu}^{3+}$ nanocrystals it was shown that decrease of the size of nanocrystal from $50 \mathrm{~nm}$ to $10 \mathrm{~nm}$ leads to increase of the oxygen vacancies concentration in 1.8 times for nanocrystals treated in neutral atmosphere and in 4 times for nanocrystals treated in reducing atmosphere.

\section{References}

1. M.Mogensen, T.Lindegaard, U.R.Hansen, G.Mogensen, J. Electrochem. Soc., 141, 2122 (1994).

2. S.Park, J.M.Vohs, R.J.Gorte, Nature, 404, 265 (2000).

3. H.Devianto, S.P.Yoon, S.W.Nam et al., J. Power Sources, 159, 1147 (2006).

4. A.S.Karakoti, N.A.Monteiro-Riviere, R.Aggarwal et al., JOM, 60, 33 (2008).

5. N.V.Skorodumova, S.I.Simak, B.I.Lundqvist et al., Phys. Rev. Lett., 89, 166601 (2002).

6. P.Dutta, S.Pal, M.S.Seehra et al., Chem. Mater., 18, 5144 (2006).

7. S.Deshpande, S.Patil, S.Kuchibhatla, S.Seal, Appl.Phys. Lett., 87, 133113:1-3 (2005).

8. A.Masalov, O.Viagin, P.Maksimchuk et al., $J$. Luminescence, 145, 61 (2014).

9. B.Tiseanu, V.I.Parvulescu, M.Sanchez-Dominguez, M.Boutonnet, J.Appl.Phys., 112, 013521 (2012)

10. M.Makayama, M.Martin, Phys.Chem.Chem. Phys., 11, 3241 (2009).

11. A.Kumar, S.Babu, A.S.Karakoti et al., Langmuir, 25, 10998 (2009).

12. M.Buijs, A.Meyerink, G.Blasse, J. Luminescence, 37, 9 (1987).

13. Y.M.Chiang, E.B.Lavik, I.Kosacki et al., Appl. Phys. Lett., 69, 185 (1996). 